\title{
Folklore and the Climate Crisis: Reading Beara as an Anthropocene Patch with Máiréad Ní Mhíonacháin
}

\author{
CALLUM BATESON, VU Amsterdam
}

\begin{abstract}
Though the term 'Anthropocene' has become dominant in discourses surrounding the climate emergency, its globalising tendencies risk discouraging grassroots action. This article argues, therefore, that in order to better understand the climate crisis, a more local approach is needed. Folklore is suggested as one such way the specific impacts of the Anthropocene can be read. To investigate, this article analyses the folklore of Máiréad Ní Mhíonacháin as a 'Capitalocene Patch', combining Anna Tsing's 'Patchy Anthropocene' and Jason Moore's 'Capitalocene' theories. In particular, this article looks at how Ní Mhíonacháin's folklore records human and non-human produced landscapes, and asks how piseoga (superstitions) might produce healthier relations with the environment.
\end{abstract}

\section{KEYWORDS}

Folklore, Anthropocene, Irish language, Ní Mhíonacháin, Environmental Humanities

The role of humanity in the climate crisis has become a key issue over the past two decades. In response to this, the term 'Anthropocene', popularised by Paul Crutzen, has been widely adopted in academic and cultural discussions around climate change (Crutzen et al. 2000). Despite this, the concept has many of its own issues. Rooted in the term anthropos, the Greek term for human, the Anthropocene implicates all of humanity equally within the climate crisis - something that is hard to justify when one considers the vast difference in carbon footprints between countries of the global north and south. Though perhaps a useful simplification, uncritical uses of 'Anthropocene' flatten and obscure global inequality, and therefore the role that economic and social systems have in shaping the current era. Furthermore, by encouraging a zoomed out, 'global' approach to climate change, it contributes to climate negativism, a feeling of hopelessness in the face of what seem like immense challenges. Few if any humans, I believe, are capable of understanding something as large and multifaceted as the climate crisis - a point eco-critic Timothy Morton enforces through the use of the term 'hyperobject' to describe the climate $(2018,77)$. He uses this term to describe phenomena which are too large to grasp or experience in their totality. In this sense, then, one might take the opinion that the term Anthropocene is unhelpful.

However, though the term is somewhat problematic, it also has worth given that climate change is a planetary issue caused by humanity. What is needed, perhaps, is not to abandon the term, but to complexify its implications. This way of thinking has already produced a range of theories and new terminology, from Donna Haraway's 'Chthulucene' to the 'Plantationocene', as used by several theorists including Anna Tsing (Haraway 2015; Tsing, Mathews and 
Bubandt 2019). These terms seek to take the Anthropocene and make a case for focussing on one specific aspect to better understand this crisis and, ultimately, to undo some of the damage. What links all such theories is a desire to zone-in on and complicate the Anthropocene narrative, to ask questions about which humans are most implicated in this crisis and to consider key issues of agency and influence. In short, they seek to break down the Anthropocene into more understandable zones, helping to combat the issue of the hyperobject. In this paper, I will apply two such theories - Tsing's 'patchy Anthropocene' and Jason Moore's 'Capitalocene' - to the béaloideas (Irish folklore) of Mairéád Ní Mhíonacháin, to ask how reading her native Beara as a Capitalocene patch might contribute to understandings of the climate crisis (Moore 2017; Tsing, Mathews and Bubandt 2019). In particular, Ní Mhíonacháin's work will be used to reveal Beara's industrial landscape, non-human victims of imperialism, and the role the supernatural has in fostering healthier human/non-human relations.

\section{Ireland and the Patchy Anthropocene}

First, the theories of the Capitalocene and patchy Anthropocene will be untangled in light of how they assist in analysing béaloideas. Moore's theory of Capitalocene insists on an economic reading of the Anthropocene. He argues that the current era has come about due to the interrelated concepts of 'cheap food' and 'cheap nature' (2017, 600). Moore describes the process of cheapening as '[...] twofold. One is a price moment: to reduce the costs of working for capital, directly and indirectly. Another is ethico-political: to cheapen in the Englishlanguage sense of the word, to treat as unworthy of dignity and respect' $(2017,600)$. This 'cheapening' has been managed by separating humans from nature and through 'rendering the work of many humans - but also of animals, soils, forests, [...] - invisible or nearly so' (Moore 2017, 600). Capitalism excludes many beings, human and non-human, and results in a 'Necrocene', with those who are surplus to the needs to capitalism devalued and/or disposed of.

Capitalism, Moore argues, is a way of organising nature and is managed through the unpaid work/energy of 'women, nature, and colonies' $(2017,598)$. This is pertinent to Ireland - as a colony - and to the folklore of Máiréad Ní Mhíonacháin who, as a speaker of a minoritised language, and as a woman, was doubly discounted in an imperial system. Ireland, described by Jane Ohlmeyer as a 'laboratory of empire,' was an early British colony, with the modern colonial period beginning with the Ireland Act (1541) and the subsequent conquest of Ireland (2004, 27). Echoing later developments, control was gained through a system of plantations, where settlers loyal to the English crown were given large portions of cleared land. Though the earlier plantations, in Munster, Offaly and Laois, were limited in their success, the Ulster plantation in the northeast would secure English control in Ireland. Throughout the modern colonial period, from 1541 to 1922, Ireland's primary role within the British Empire was as a producer of food. Though the country is best known today for pasture-based agriculture, until the Famine, arable farming, especially the cultivation of corn, was central to the Irish farming economy (Ó Gráda 1990, 168). Using Moore's theory, it can be understood that Ireland was valuable as a place where 'cheap food' could be obtained. It thus follows that there would be living beings deemed surplus to the utilitarian needs of extractivist capitalism. In the case of 
Ireland, this included its forests and many native species, including the wolf, the great crane and St Patrick's wort.

Colonialism in Ireland also came at great human cost. The early modern colonial period (1541 to 1691) was marked by war, famine and disease, especially during the Cromwellian wars in the 1640 s and 1650s. Some two hundred years later, over a million people would die in the Great Famine (1845 to 1852) from disease and hunger following the failure of the potato crop. Most historians agree that this scale of death is attributable to British policymaking at the time (Gray, 2020). As such, it is perhaps unsurprising that Moore himself includes Irish people, historically speaking, as an example of a people excluded from modernity, alongside indigenous groups and women. This inclusion, however, needs to be more nuanced. While Irish people, as is explored above, suffered under colonialism, over time they became racialised as white, and though anti-Irish sentiment remained common well into the twentieth century in the USA and UK, white Irish migrants nonetheless benefitted from opportunities not available to people of colour, or indeed Irish travellers/Mincéirí. Crucially, Ireland today, as a wealthy EU member state, participates in neo-imperial flows of capital. ${ }^{1}$

If one needs to tread carefully when considering Ireland within a colonial context or as a victim of the Capitalocene, this does not mean it should not be considered at all in this light. As an early colony located in Europe, it represents a peculiar case in the history of imperialism, while its subsequent position, from the nineteenth century, as both a victim of empire and an oppressor, can aid understanding of the centrality of economics and class to the European imperial project. If some Irish people, mostly from the Protestant ascendency class, participated in and profited from empire as soldiers, landowners and traders, many others suffered as poorly paid, landless labourers, and it was this latter group which was affected most by the Famine (Reilly 2020). Furthermore, though English became an increasingly dominant language in Ireland during the 1800 s, even by the end of that century there remained hundreds of thousands of monolingual Irish speakers who were denied the right to deal with state apparatus or courts through their first language and were therefore dispossessed of justice. ${ }^{2}$ In short, although it cannot be said that all of Ireland, or all Irish people, were excluded from capitalism and systemically oppressed, certain groups, particularly poor Irish speakers and travelling people, were.

It is useful to expand on Tsing's theory of the patchy Anthropocene here, which she defines as '[...] the uneven conditions of more-than-human liveability in landscapes increasingly dominated by industrial forms' $(2019,186)$. That is to say, landscapes are taken and examined in light of networks of actors, human and non-human. Tsing uses 'patches', or specific contact zones, to create a theory that functions on both a local and planetary scale. The plantation is taken as an example of such a patch where human/non-human relations can be read to better understand the Anthropocene - one where 'ecological simplifications', such as monocropping,

\footnotetext{
${ }^{1}$ Ireland's current economic model relies on foreign direct investment from multinational companies attracted by low corporation tax rates. This costs other countries at least sixteen billion dollars in lost tax revenue every year. See: https://www.irishtimes.com/business/economy/tax-evasion-in-ireland-costs-other-countries-16bn-ayear- 1.4414706

${ }^{2}$ Evidenced by the Maamtrasna case in 1882, where Maolra Seoighe, a monolingual Irish speaker, was wrongly convicted of murder and executed. See: https://www.thejournal.ie/maamtransna-murders-4394952-Dec2018/
} 
have led to 'feral proliferations' of non-human actors who thrive in such environments, outside of the control of people $(2019,189)$. Folklore has a key role to play in interpreting 'patches', as it tends to be deeply rooted in the local, weaving human and more-than-human narratives together. Its importance to climate crisis conversations is underlined when one adds an economic reading, which highlights the exclusion of rural Irish-language speakers, and their culture, from imperial modernity. If part of Tsing's 'art of living on a damaged planet' is unlearning some of the toxic patterns that have emerged since the rise of the Capitalocene, it follows that folklore might be one place to start (2017). For the purposes of this paper, I will be using Ní Mhíonacháin's folklore as an example of understanding the patch of the Beara peninsula.

\section{The Anthropocene in Beara}

Firstly, it is important to provide some background on Máiréad Ní Mhíonacháin and the collection Béarrach Mná ag Caint ('A Beara Woman Talking'). This collection is of interest for a number of reasons. Firstly, it is a relatively rare example of published female folklore. All full-time collectors employed by An Coimisiúin Béaloideas (The Folklore Commission) were men and, as a result, most archival material comes from male informants (Ní Churraighín 2015). This represents an unknowable loss and highlights the importance of foregrounding those non-male voices that do exist in the collection. Moreover, if 'the Anthropocene must be apprehended in the specificity of its impacts in different locations over time rather than in terms of undifferentiated, systemic flows that describe much and explain little,' the regional specificity of this collection is of much relevance (Cronin 2017, 17). Ní Mhíonacháin was born on the Beara peninsula in County Cork in 1861 and lived there until her death in 1957, inheriting knowledge that was passed down intergenerationally (Ní Mhíonacháin, Ó Murchú and Verling 1999, 12). Though the stories relate to a small corner of the world, they come into contact with, and relate to, global flows. As a peripheral region of empire, the Beara peninsula fits Klein's definition of sacrifice zones as areas that 'don't count', which function as 'disposable peripheries to glittering (imperial) centres' (Klein 2015, 225).

Despite its remoteness, evidence of empire is scattered throughout Beara. The English maintained a naval base at Berehaven until after the 1938 Anglo-Irish Trade Agreement. The peninsula was badly affected by the Famine - from a peak of almost five thousand in 1841, the population of Cill Chaitiarn, the townland in which Ní Mhíonacháin was born, fell to less than eighteen hundred by 1926 (All-Island Research Observatory 2016). Today, it is home to just eight hundred people (Central Statistics Office 2016). A similar pattern can be observed in terms of language use. Though at the time of independence in 1922 the majority of the population was still Irish speaking, in the latest census just 4\% reported that they used Irish regularly outside of the education system (Central Statistics Office 2016). ${ }^{3}$ These precipitous declines can be attributed to imperial capitalism, which created the conditions for the Famine,

\footnotetext{
${ }^{3}$ This figure is a combination of those who, according to the 2016 Census, reported speaking Irish daily or weekly outside of the education system.
} 
before introducing an industrialised farming system that required less labour and systemically exported profits from the region.

Ní Mhíonacháin represents an example of how wider structures affect individual lives. Of her twelve children who reached adulthood, only two remained in Ireland, and the economic and social conditions which led to the decline of Irish as a vernacular in this region meant that she did not pass on the language to her own children (Ní Mhionacháin, Ó Murchú and Verling 1999, 23). This was likely influenced by her own experience with the school system. She recalls 'fad a bhíos-sa ar scoil ní raibh focal gaelainne á labhairt agam' ['While as I was in school I didn't speak a word of Irish'] even though 'bhí morán ag teacht gan dabht na raibh aon fhocal Béarla acu ach Béarla briste' ['without a doubt there were many who came with little or no English’] (Ní Mhíonacháin Ó Murchú and Verling 1999, 76). The interconnection between colonial laws decreed from distant London, which in the late nineteenth century would have taken a week of travel to reach Beara, and Ní Mhíonacháin's personal life represents what Rob Nixon calls 'slow violence' $(2013,2)$. In other words, Ní Mhíonacháin became a personal victim of colonialism, not through direct means, but through a process of erosion. Slow population decline and the decision to raise children in one language over another are barely perceptible events when viewed individually, but together they accumulate to an inventory of losses whose impacts spread well beyond the periphery.

In order to place Máiréad Ní Mhíonacháin's folklore in the context of the Capitalocene, attention will now be drawn to Beara's past as a centre for copper mining. Though the coast and mountains are quiet today, with little economic activity outside of agriculture, the area would have been full of human activity when Ní Mhíonacháin was young. Allihies, twenty kilometres west of Ní Mhíonacháin's home, was once a major centre for copper extraction. In the mid-nineteenth century, twelve hundred people worked in its mines, extracting wealth from the surrounding landscape (O'Connell 2009, 9). The ghosts of ruined pumphouses and mineshafts remain, and a decaying network of tunnels led to a sinkhole in 2018. The industry had little benefit for local people, as the copper was sold for use across the British Empire and much of the profit kept by owner John L. Puxley (O'Connell 2009, 9). These mines existed as a patch of the Capitalocene and can be understood as a microcosm of settler/native tensions on the edge of Europe. Leadership positions were given to Cornish miners, who enjoyed far better pay and housing conditions than the Irish miners (O'Connell 2009, 11). Divisions of language (between English and Irish) and religion (Methodism and Catholicism) exacerbated such tensions and led to strikes in 1868 (O'Connell 2009, 11). Ultimately, both Cornish and Irish miners lost out as cheaper copper from Chile rendered the mine unprofitable and led to emigration to mining towns (notably Butte in Montana, US).

Beara's industrial past is present in Béarrach Mná ag Caint in several ways. Two of Ní Mhíonacháin's sons left for Butte, Montana in the 1880s and never returned, and there is evidence in her folklore that older herbal remedies were adapted to industrial illnesses (Ní Mhionacháin, Ó Murchú and Verling 1999, 24). The interaction between capitalism, folklore, and non-human agents in Beara is best shown through a section exploring uses of the herb camomile. Ní Mhíonacháin explains how wild camomile was harvested, dried and brewed into a tea (Ní Mhionacháin, Ó Murchú and Verling 1999, 100). This was 'go maith don té go 
mbeadh decay air' [good for someone who was suffering from decay]. Decay here means tuberculosis that was acquired through breathing particulate-heavy air in the mines. Though the mines in Allihies closed when Ní Mhíonacháin was a child, this shows that people in the area suffered from its aftereffects for decades to come. The illnesses suffered by former miners underline Beara as a site of the Capitalocene and represent another example of Nixon's 'slow violence'. Returning to Beara as a 'patch' of the Anthropocene, one can understand the mine as an 'ecological simplification', where humans have impacted and attempted to control the landscape. Similarly, one can understand lung diseases such as tuberculosis as a 'feral proliferation', something caused by humans but that is out of their control. Though these lives and illnesses have long since vanished from the consciousness of the area, the ruins of the copper mines remain, occasionally breaking into the public consciousness when sinkholes form above former mine shafts. The physical remains of industry and Ní Mhíonacháin's account of how camomile was used for tuberculosis remind the reader of Beara's position within a global extractivist system, and underline how imperialism relied on its peripheries. If Beara was just another anonymous cog in an imperial economic system for copper traders, Ní Mhíonacháin's personal life and herbal knowledge underlines Tsing's statement that 'none of us live in a global system, we live in places' $(2016,3)$. That is to say, to understand the system, it is necessary to understand the local components, and the tangled web of relations within such areas.

It is not just the industrial scape that should be remembered when looking at Beara as a patch. Though the modern day is mostly devoid of forests and large mammals, this was not always the case. If today's bare mountains attract praise for their beauty, they also serve to hide former habitats by suggesting permanence, reflecting Tsing's assertion that 'admiring one landscape entails forgetting others' $(2016,6)$. Away from the mines, capitalism has had an immense impact on the physical map of Beara, with much of the original forest cut down during the early colonial period. Ní Mhíoncháin demonstrates this, recalling that woods used to stretch between Scoil a Chalaidh Ros and Droichead Á'Dhroim, but 'caitheadh iad a ghearradh mar bhíodar i ngátar na tine' ['they had to be cut down for firewood'] (Ní Mhionacháin, Ó Murchú and Verling 1999, 99). It is almost jarring to imagine forested valleys in an Irish context, but Ní Mhíonacháin's recollections underline that in many places this would have been the case. These forests were home to a wide range of species, and it is unsurprising, therefore, that in Béarrach Mná ag Caint references are made to 'cait crainn' ['pine martens'] and 'cait fhiacais' ['wild cats']. Indeed, at one point there seems to have been an abundance of the latter as 'síos fén reilg [...] bhí an áit lán díobh' ['down by the graveyard [...] the place was full of them']. However, 'chuireadar tine sa scairt [...] chuir san deireadh leis' ['The bushes were set alight [...] and this put an end to them'] (Ní Mhionacháin, Ó Murchú and Verling 1999, 99). The losses in this patch were reflected across the island. Though in a global context this may seem like a mere footnote, by connecting the local losses present in Ní Mhíonacháin's recollections to those in other Anthropocene patches, they amount to what is termed extinction.

While some species have long since vanished, that the pine marten and the wild cat are mentioned in folklore passed on in the late-nineteenth and early-twentieth centuries suggests that they were widespread until relatively recently. The pine marten, hunted nearly to extinction, has made a comeback in parts of Ireland, though it remains rare in West Cork, but the wild cat is an animal that has almost been forgotten. Indeed, early twentieth-century reports 
from a naturalist question if there ever was such an animal in Ireland, suggesting that reported sightings may just have been feral housecats (Warren 1913, 94). However, given the continued presence of the wild cat in northern Scotland it seems unlikely such an animal would not have been present in Ireland. In addition, the use of the separate term 'cait fhiacais' by Máiréad Ní Mhíonacháin to indicate a tree dwelling, cat-like animal strongly suggests the presence of wild cats in Beara. Further evidence of the presence and importance of this species to the area is highlighted by the presence of a place called Lios na gCait [Fort of the Cats] (Ní Mhionacháin, Ó Murchú and Verling 1999, 144). That these cats had a long and significant enough presence to be recorded in placenames strongly suggests a native, wild species. As non-human narratives tend to be side-lined in grand historical ones, other sources are needed to bear witness to former habitats.

In an Irish context, placenames can be invaluable in this sense, existing as a ghost map of former species. In these names, the wild boar still haunts Ceann Toirc, the eagle Gleann an Ílair and the wolf Faol Droim. This highlights the connection between Irish as a language and the landscape it developed in - and its fundamental role in holding the patch together, connecting human, non-human and landscape through folklore and naming traditions. Much of this knowledge is under threat - colonialism in Beara cost the region its language and started a process of population decline which emptied townlands, shattered communities and closed schools, remapping the human landscape. In tandem, the natural landscapes lost the species which gave them their names. Even these are at risk of disappearing, as fewer people use such names and the reason behind them is forgotten. This forgetfulness, or perhaps even submission to the modern age shaped by imperialism, is not inconsequential, as it is not just the stories that are lost but the respect for and, crucially, knowledge of the land and the understanding of how interconnected humans are with the world around them. This loss of awe and respect for nature, embodied by seventeenth-century English philosopher Francis Bacon's belief that Earth should be 'knowable' and 'controllable', can be connected with the ongoing desecration of the natural environment that has given rise to the Anthropocene (Klein 2015, 226). Regardless of the motivation, if a community or individual respects and appreciates the natural world, they are less likely to destroy it.

\section{Piseoga, Superstition, and the Need for Respect}

While I have concentrated thus far on the physical and economic aspects of Beara as a patch, Ní Mhíonacháin's folklore also places a great emphasis on the non-physical and the supernatural as part of this world. I will now examine how piseoga (superstitions) and a belief in the supernatural helped maintain a respect for nature. One of the fundamental issues of the Anthropocene is alienation from the natural world; as Tsing notes, 'alienation produces the dilemmas we call Anthropocene' $(2016,4)$. That is to say that as humans have become more entangled with the rituals of capitalism, the link between humanity and the Earth has been weakened. If something feels outside one's lived experience, it is hard to care much about it. By this logic, if nature has been reduced to a pitiful aspect of the human experience, unable to 'compete' with neoliberal society, the fault lies with nature's vulnerability rather than humanity's consumption; it has been, to return to Moore, cheapened in all senses. Like a worker 
who becomes too old or too sick to work, nature is constructed as something to be cast off, to be replaced by the next big technological innovation.

How can industrial humanity, bound mostly to the cities, re-learn respect for the rest of nature? The idea of fostering academic theory to help us understand the interconnected world - such as Deleuze and Guattari's 'rhizome' - is technically a respectable one (Deleuze and Guattari 2005). However, I would argue that it requires time and educational privilege to access, understand and internalise such philosophies. If a large part of the problem with climate change is that we 'can't see it, so we don't really believe it exists', then surely part of the challenge is to make its effects visible to us (Klein 2015, 223)? This is where it is interesting to look at how folklore deals with these relations, using the supernatural to maintain a sense of respect for life beyond the human. One of the recurring elements within these folklore tales concerning the supernatural is a sense of consequence. This can be seen in many stories. For example, there was a common belief that at midnight on Christmas Eve, water in wells would be turned into wine - a belief which echoes the New Testament 'Wedding at Cana' miracle. Though one would think that the appearance of free alcohol would see many people gathering at their nearest well, there were consequences for behaviour that broke the sanctity of Christmas night. In one story, it is told that one girl who looked in the well was turned into a 'tom aiteann' ['gorse bush'], while two enterprising men who planned to sell the wine left, never to be seen again. ${ }^{4}$ Respect for traditions and for the spiritual world held importance, as a way to protect both the individual and surrounding societal structures.

In relation to the natural world, it is interesting to look at the story 'Máire Ní Mhurchú agus an giorré' ['Máire Ní Mhurchú and the Hare']. Máire Ní Mhurchú is a recurring figure in Béarrach Mná ag Caint, as someone who is able to slip between both the physical and otherworld and communicate with the 'daoine maithe' ['fairies', lit. 'good people'] (Ní Mhionacháin, Ó Murchú and Verling 1999, 123). The Irish language codifies this multiplicity of worlds linguistically with the words ceantar and altar. The former means 'area' in the sense of a physical space, while the latter also implies 'area', but one that is unseen - a reflection of this world. While ceantar and altar rarely came into direct contact with each other, the acknowledged existence of another, unknowable reality created a world of superstitions. The non-human world did not just encompass animals, plants and the physical landscape, but also spirits, fairies and the dead. If the Global North has forgotten how to deal with what once was with negative results - 'the refusal of the past and even the present will condemn us to continue fouling our own nests' (Tsing et al. 2017,2) - then the society of Ni Mhíonacháin was almost the opposite of this, as there was an understanding that the past could erupt at any given moment through the supernatural. In the case of 'Máire Ní Mhurchú agus an giorré', a boy goes out on an errand and is followed by his family's hound (Ní Mhíonacháin, Ó Murchú and Verling 1999, 123). On the way, a hare jumps out of a hole and the boy sends the dog after it, leading to the animal being mauled by the dog. Once the boy returns home, he falls sick and nothing his mother does seems to revive him. The next day, the mother encounters Ní Mhurchú who laughs and asks why the boy set the dog on the hare explaining: 'Ní giorré a bhí ann ach seananbhean'

\footnotetext{
${ }^{4}$ See https://tuairisc.ie/o-dhuchas-biodh-nollaig-mhor-mhaith-dhuchasach-agaibh-bigi-lach-lena-cheile-agus-gombeirimid-beo-ar-an-am-seo-aris. (Article in Irish) (Accessed 9 January 2021).
} 
['That wasn't a hare but an old woman'] (Ni Mhíonacháin, Ó Murchú and Verling 1999, 123). Ní Mhurchú tells the mother how to cure her son, but he learns a lesson as 'go dtí an lá a fhág sé Éireann chun dul go dtí Meirice níor chuir sé aon ghadhar i ndiadh aon ghiorré' ['until the day he left Ireland for America he never set a hound on any hare'] (Ni Mhíonacháin, Ó Murchú and Verling 1999, 123). As a type of miniature bildungsroman, this story teaches the reader that one should respect nature, as the consequences for intervening may be severe.

The ability for the hare to be an old woman also presents a rejection of 'Man' as an all-powerful force, removed from the rest of nature. Instead, the narrative places humanity within nature, demonstrating that we should respect it, because to do so is to respect ourselves. This story is the embodiment of Tsing et al.'s appeal that 'we must wander together through landscapes where assemblages of the dead gather with the living', recognising how this means observing the physical way marks of former inhabitants are left on landscape (2017, 5-6). In this light, Tsing, Mathews and Bubandt reference the ability of oak trees to regrow from stumps as an inheritance from when such trees were trampled by elephants (1999, 6). In Ireland, old mountain goats developed large, sharp horns to defend themselves from wolves; the nonhuman world was respected not out of romance, but of necessity. As folklorist Kate Chadbourne points out, 'rituals may evolve to help deal with fear and risk' $(2012,73)$. It is no surprise that it was in fishing communities on the Atlantic, where food production literally meant facing death on a daily basis, that piseoga were particularly enduring. Indeed, the extent of the entanglement between humans and the rest of nature was such that. in many such stories, 'human beings sometimes acted like the sea and sometimes like fairies' (Chadbourne 2012, 73). While the threat to human life on farms was perhaps less immediate, the connection between a healthy landscape and survival was evident.

The importance of livestock is shown by supernatural stories that feature cows. In one such tale, Ní Mhíonacháin recalls 'na ba ón saol eile' ['cows from the other world'] that were 'dath na bhfaca sé riamh' ['a colour he [the character] had never seen before'] (Ni Mhíonacháin, Ó Murchú and Verling 1999, 143). In opposition to Christian ontologies that place humans, and in particular Tsing's 'Man' on top of a hierarchy, the importance of other animals to the survival of the community meant that older, pre-Christian belief systems endured alongside Catholicism. It is unsurprising that the cow in particular is singled out as having an afterlife; though the centrality of beef and dairy to the Irish agri-food industry is an imperial inheritance, ${ }^{5}$ the cow has long held an important role within Irish society. Indeed, one of Ireland's main epic cycles is titled 'Táin Bó Cuailgne' [The Cattle Raid at Cooley], and wealth was often measured in terms of livestock. Moreover, many words in Irish such as bóthar (road), tairbhe (productive) and bóthain (shed) derive from words for cow and bull. It is important to note that the cow was seen as a precious animal, and beef was generally eaten only on special occasions.

\footnotetext{
${ }^{5}$ Pre-Famine, Ireland was renowned for its soil quality and had a diverse agricultural output. However, the collapse of native systems of land management led to a depletion of soil nutrients and the replacement of small, mixed farms with large dairy and meat plantations (Slater and McDonough 2008). A century after independence, Irish agriculture remains locked into this system. The country produces nine times more dairy than is consumed internally and the sector relies heavily on the former colonial power, Britain, for exports. The environmental consequences are dire - according to a 2020 EPA report, only $22 \%$ of Irish river systems are of excellent quality (Environmental Protection Agency 2020).
} 
Recalling past times, Ní Mhíonachain tells us that 'ní itheadh aon fhear na aon bhean ná aon bhá ná aon caora aon ubh i rith na bliana ach ar Domnach Cásca - bhí an saol bocht, go bhfóire Dia orainn' ['No man nor woman ate any cow or sheep or egg during the year except for Easter Sunday - life was poor, God protect us'] (Ní Mhíonachain, Ó Murchú and Verling 1999, 112). While this may be somewhat exaggerated, it highlights how scarce animal products were and the abnormality of modern life with its freely available and cheap meat and dairy.

This raises questions around why industrial humanity is 'willing to turn things into rubble [...] destroy atmospheres and sell out companion species in exchange for dream worlds of progress' (Tsing et al. 2017, 2), when just a few generations ago, community beliefs largely prevented such actions. I would suggest that the structure of contemporary societies in late capitalism militates against the formation of rhizomic or flat ontologies because of many peoples' alienation from the means of production. The financial, human and environmental capital required to produce food is invisible, and so even if one knows, technically, that six eggs should not cost less than a euro, it is easy to ignore. In Cill Chaitiarn, when Ní Mhíonacháin was growing up, the immediacy of nature and the direct role people played in producing and supplying food would have made understanding such interconnections much easier. The challenge that is faced is understanding that just because something is not (immediately) visible does not mean it does not exist. As is shown above, the supernatural and spirit worlds once performed this role in rural communities, rendering the invisible visible and fostering an understanding of how the past and present interact with each other.

This is not to advocate for a wholesale return to such belief systems, which would likely be impossible in any case. However, Chadbourne's contention that folklore stories 'imply that the best way to remain safe is to conform to the rest of the community [...] to observe its rhythms and patterns carefully' perhaps offers insights into how industrial humanity can develop a sense of environmental responsibility $(2012,79)$. Piseoga and belief systems were upheld through strong community structures in places such as Cill Chaitiarn, and their survival was ensured by an intergenerational system of knowledge transmission. The fracturing of these communities led to the demise of such systems of knowledge, and with them a loss of respect for nature and the past. Through reconstructing the supernatural, as well as the physical narrative of Beara as a patch, and connecting this with the community, perhaps environmental awareness can once more be embedded as a norm. This is just one local example, but it demonstrates the possibilities of utilising Tsing's patch theory to tell the stories of local places - and such stories will vary depending on the region. In the case of Beara, while people may scorn piseoga and the supernatural, these belief systems helped ensure balance in human/non-human relations for thousands of years, and so it would seem somewhat foolish to entirely overlook them in the search for post-Capitalocene ways of living with the planet.

\section{Conclusion}

This paper started by identifying the impossibility of dealing with the climate crisis in its global entirety, and that to attempt to do so, as is suggested by the term Anthropocene, tends to lead to disillusionment and a feeling of helplessness. To ameliorate this, Tsing's theory of a patchy Anthropocene and Moore's Capitalocene were suggested as ways to situate the climate crisis 
in the local, through zoning in on specific places (Tsing's 'patches') and systems (capitalism) to read the global. By examining Anthropocene as a result of capitalism, the importance of imperialism to understanding the climate crisis is revealed. Folklore, I have argued, is an ideal test ground for such theories as it tends to be grounded in the hyperlocal, embodying intergenerational notions of place and community. Furthermore, as much of such knowledge is produced in minoritised languages, by non-elites, it offers a worldview that is somewhat apart from hierarchical Western Enlightenment thinking, even if it maintains a dialogue with such ideologies. Máiréad Ní Mhíonacháin's folklore, embedded within the Beara peninsula where she was born and died, helps demonstrate this, showing how imperialism interacts with the human and non-human cultures it seeks to suppress on the periphery of empire.

In this paper, I first examined how the industrial legacy of Beara, in the form of copper mines, has influenced Ní Mhíonacháin's folklore. This is most evident in the way that certain traditional herbal remedies were reappropriated to deal with the diseases of extractivism (in this case, respiratory illnesses caused by mining). Despite Beara's remoteness in relation to imperial centres of commerce, globalisation influenced the region strongly; the copper mines closed in 1868 due to price competition from Chilean mines. Though Ní Mhíonacháin never visited South America, her life would be directly affected by changes in the global trade system; all but two of her children would emigrate, and despite her own attachment to the Irish language (made clear by the fact this collection exists at all) she would raise her children in English. With few opportunities available in Beara, combined with the inherited trauma of famine and the systemic enforcement of the English language under colonial rule, I would argue she had little choice. By thinking of Beara as a patch of imperialism, local decisions such as raising a child in a certain language or using camomile in a specific way can be read as symptoms of a history of marginality. This way of thinking was then applied to the non-human impacts of imperialism (and therefore the Anthropocene) in Beara, as shown in Ní Mhíonacháin's work. Though Beara's modern landscape suggests permanency, Béarrach Mná ag Caint reveals a patch that has changed greatly. The deforestation of Ireland is recorded in the micro-level, in a muted statement that between two small places there was once woodland. Though this might appear insignificant in the scale of habitat destruction more generally, it has wider ripples. The presence, and disappearance of two species - the wild cat and pine marten - from Beara is noted by Ní Mhíonacháin, and these nineteenth-century regional extinctions echo earlier disappearances from this patch, most notably the wolf. If folklore is important in preserving the existence of humans almost erased by history, this is even more true in terms of the nonhuman. Though the memory of the wolf, for example, is well-preserved in Ireland, this is not the case with most vanished species. The wild cat has almost been forgotten as a once-native inhabitant of Ireland, but through examining Ní Mhíonacháin's recollections and drawing attention to Irish language placenames, its former presence is made clear. Her folklore serves therefore as a testimony, bearing witness to that which has been lost in the throes of extractivist imperialism and capitalism.

Much of this paper might seem like a record of decay and destruction, and folklore just a way to remember neglected histories. However, the final section of this paper suggests that elements of béaloideas might help us rethink human/non-human relations through examining the way superstition and a belief in the supernatural functioned to maintain a balanced relationship with 
the environment. Though some piseoga existed to perpetuate oppressive societal structures, I have shown how many superstitions build respect for the non-human, and how a belief in the supernatural connected the past to the present, potentially fostering a desire to care for the environment for future generations. Such systems were intimately linked to the Irish language, and its decline, alongside emigration which meant that most of this knowledge has been lost. Though there is much to mourn, I wish to conclude this paper on a somewhat hopeful note - Ní Mhíonacháin's folklore is also a story of resistance. Despite centuries of oppression, the Irish language still exists as a community vernacular (even if not in Beara), and though the béaloideas tradition has largely vanished, its existence into the mid-twentieth century and the independent Irish state has meant that significant amounts have been preserved, and even digitised. In a local triumph for the non-human, the pine marten, almost extinct in Ireland half a century ago, has since returned and is credited with increasing red squirrel populations. Often, those with political power parrot the Thatcherite tenet that there is no alternative to the current economic system, but the wealth of alternative knowledge and ways of being that are carried in folklore across the world show that there are myriad ways of living with the Earth. By foregrounding Tsing's theory of the patchy Anthropocene, perhaps these zones of being can be knitted together to imagine a more caring future, in which all that live on this planet are accounted for.

\section{References}

All-Island Research Observatory (AIRO) (2016) Famine Mapping - 1841-1851: County Cork. Available at: http://airo.maynoothuniversity.ie/external-content/famine-mapping-18411851-county-cork (Accessed: 9 January 2021).

Apter, E. (2013) Against World Literature: On the Politics of Untranslatability. London: Verso.

Briody, M. (2015) Irish Folklore Commission 1935-1970. Helsinki: Finnish Literature Society.

Central Statistics Office (CSO) (2016) Census 2016 Small Area Population Statistics: Cork. Available at: http://census.cso.ie/sapmap/ (Accessed: 10 January 2021).

Chadbourne, K. (2012) 'The Knife Against the Wave: Fairies, Fishermen, and the Sea', Béaloideas, 80, pp. 70-85.

Cronin, M. (2017) Eco-Translation: Translation and Ecology in the Age of the Anthropocene. London: Routledge

Crutzen, P. and Stoermer, E. (2000) 'The "Anthropocene", Global Change Newsletter, 41, pp. 17-18.

Deleuze, G. and Guattari F. (2005) A Thousand Plateaus: Capitalism and Schizophrenia. Minneapolis: University of Minnesota Press.

Environmental Protection Agency (EPA) (2020) River Monitoring Factsheet. Available at: https://www.epa.ie/pubs/reports/water/waterqua/EPA_River_Monitoring_Factsheet_June202 0.pdf (Accessed: January 9 2021). 
Erickson, B. (2020) 'Anthropocene futures: Linking colonialism and environmentalism in an age of crisis', Environment and Planning D: Society and Space, 38(1), pp. 111-128.

Gray. P. (2020) 'A policy disaster: how British famine relief measures failed to quell the devastation of the Famine'. RTÉ. 2 December. Available at:

https://www.rte.ie/history/famine-ireland/2020/1123/1180004-a-policy-to-disaster-britishfamine-relief-measures/ (Accessed: 9 June 2021).

Haraway, D. (2015) 'Anthropocence, Capitalocene, Chthulhucene. Donna Haraway in Conversation with Martha Kenney', in Davis, H. and Turpin, E. (eds.) Art in the Anthropocene: Encounters Among Aesthetics, Politics, Environments and Epistemologies. London: Open Humanities Press, pp. 255-271.

Kiberd, D (2009) Inventing Ireland. New York: Vintage.

Klein, N. (2015) This Changes Everything. New York: Simon \& Schuster.

Maldonado-Torres, N. (2016) 'Outline of ten theses on coloniality and decoloniality', Fondation Frantz Fanon. Available at: http://fondation-frantzfanon.com/wpcontent/uploads/2018/10/maldonado-torres_outline_of_ten_theses-10.23.16.pdf. (Accessed: January 9 2021).

Moore, J. (2017) 'The Capitalocene, Part I: On the Nature and Origins of Our Ecological Crisis', The Journal of Peasant Studies, 44(3), pp. 594-630.

Morton, T. (2018) Being Ecological. Cambridge, MA: MIT Press.

Ní Churraighín, A. (2017) 'Béal Bocht An Bhéaloidis: Myles Na Gcopaleen Agus A LuathChritíc Ar An Bhailiú Ghairmiúil', ComharTaighde, 3. Available at:

https://comhartaighde.ie/eagrain/3/nichurraighin/ (Accessed: 9 January 2021).

Ní Mhionacháin, M., Ó Murchú, T. and Verling, M. (1999) Béarrach Mná ag Caint: seanchas Ní Mháiread Mhionacháin. Indreabhán, Conamara: Cló Iar-Chonnachta.

Nixon, R. (2013) Slow Violence and the Environmentalism of the Poor. Cambridge, MA/London, England: Harvard University Press.

O'Connell, M. (2009). 'What a pity at the very source of wealth! Strikes and emigration, Berehaven mining district, 1861-c.1900', Saothar, 34(1), pp. 7-18.

Ohlmeyer, J.H. (2004) 'A Laboratory for Empire? Early modern Ireland and English imperialism', in Kenny, K. (ed.) Ireland and the British Empire. Oxford: Oxford University Press, pp. 26-60.

Ó Gráda, C. (1990) 'Irish Agricultural History: Recent Research Work in Progress', The Agricultural History Review, 38(2), pp. 165-174.

Reilly, C. (2020) 'Hidden Ireland: The world of the cottier on the eve of the Famine', RTÉ, 25 November. Available at: www.rte.ie/history/the-great-irish-famine/2020/0806/1157723hidden-ireland-the-world-of-the-cottier-on-the-eve-of-the-famine/. (Accessed: June 9 2021).

Shokouhi, M. (2019). 'Despirited Forests, Deforested Landscapes: The Historical Loss of Irish Woodlands', Études irlandaises, 44(1), pp. 17-30. 
Slater, E. and McDonough, T. (2008) 'Marx on nineteenth-century colonial Ireland: Analysing colonialism as a dynamic social process', Irish Historical Studies, 36(142), pp. 153-172.

Tsing, A. L. (2016) 'Earth Stalked by Man', The Cambridge Journal of Anthropology, 34(1), pp 2-16.

Tsing, A. L., Swanson, H. A., Gan, E., and Bubandt, N. (eds.) (2017) Arts of Living on a Damaged Planet: Ghosts of the Anthropocene. Minneapolis: University of Minnesota Press.

Tsing, A.L., Mathews, A.S. and Bubandt, N. (2019) 'Patchy Anthropocene: Landscape Structure, Multispecies History, and the Retooling of Anthropology: An Introduction to Supplement 20', Current Anthropology, 60(20), pp. 186-197.

Warren, R. (1913) 'Wild Cats in Ireland', The Irish Naturalist, 22(5), pp 94-96.

Callum Bateson is a postgraduate researcher at VU Amsterdam. His research interests include the Capitalocene, minority languages, and contemporary Ireland as a (post)colonial space. He holds an MPhil in Creative Writing from Trinity College Dublin, and his creative work has been published in the College Green Journal. He has a forthcoming academic publication in Imaginaries journal.

Email: c.p.bateson@student.vu.nl 